\title{
FAKTOR-FAKTOR PENGARUH RETURN ON INVESTMENT
}

\author{
Chaidir dan Mira Pitriana \\ Fakultas Ekonomi Universitas Pakuan \\ E-mail: chaidir_ofla@yahoo.com
}

\begin{abstract}
ABSTRAK
Penelitian ini bertujuan untuk menganalisis pengaruh rasio leverage, pertumbuhan penjualan dan ukuran perusahaan terhadap return on investment pada perusahaan sub sektor plastik dan kemasan yang terdaftar di Bursa Efek Indonesia periode tahun 2013-2016. Dalam penelitian ini, rasio leverage diukur menggunakan Debt to Equity Ratio (DER), Degree of Financial Leverage (DFL), Sales Growth (SG) dan Firm's Size (Size). Penelitian ini menggunakan data sekunder dan metode penarikan sampel dengan purposive sampling. Metode analisis yang digunakan yaitu secara statistik yang terdiri dari statistik deskriptif dan inferensial dengan menggunakan analisis regresi linier berganda, uji asumsi klasik, dan uji hipotesis dengan bantuan software Statistical Product and Service Solution (SPSS) versi 20.0. Hasil penelitian menunjukan bahwa koefisien determinasi ( $R$ square) dalam penelitian ini sebesar 0,531 atau 53,1\%. Sedangkan sisanya dipengaruhi oleh variabel lain. Pengujian hipotesis menggunakan uji $F$ menunjukkan bahwa $\mathrm{F}$ hitung $>\mathrm{F}$ tabel $(4,217>2,14)$ dengan nilai signifikansi $0,005<0,05$. Artinya $D F L, S G$ dan Firm's Size secara simultan berpengaruh positif signifikan terhadap return on investment, sedangkan pengujian hipotesis menggunakan uji t menunjukkan bahwa nilai debt to equity ratio ($2,068<1,607<2,068)$, nilai degree of financial leverage $(-2,068<0,763<2,068)$, nilai sales growth $(-2,068<0,583<2,068)$ dan nilai firm's size $(-2,068<-1,577<2,068)$ dengan $-\mathrm{t}$ tabel $<\mathrm{t}$ hitung $<\mathrm{t}$ tabel dan nilai signifikan $>0,05$ yang artinya tidak berpengaruh signifikan terhadap return on investment.
\end{abstract}

Kata Kunci: Debt to Equity Ratio (DER), Degree of Financial Leverage (DFL), Sales Growth (SG), Firm's Size (Size), Return On Investment (ROI)

\section{LATAR BELAKANG}

Aktivitas sebuah industri merupakan usaha produktif yang dilakukan oleh suatu negara yang direfleksikan dalam bidang produksi. Kata produksi sering disebut sebagai aktivitas manufaktur (manufacturing). Di Indonesia pertumbuhan industri manufaktur begitu pesat, dapat dilihat dari perkembangan perusahaan manufaktur yang terdapat di Bursa Efek Indonesia (BEI) dari tahun ke tahunnya semakin bertambah. Salah satu industri yang mengalami pertumbuhan positif adalah industri plastik dan kemasan. Hal ini dapat dilihat dari peningkatan jumlah emiten sektor industri plastik dan kemasan yang jauh lebih besar dari sektor lainnya.
Pada umumnya perusahaan tidak mungkin beroperasi dalam kondisi stagnan. Pengembangan ekonomi dan tindakan pesaing mempengaruhi kemampuan perusahaan untuk mencapai keberhasilan. Setiap perusahaan akan melakukan berbagai aktivitas untuk mencapai tujuan yang diharapkan. Di berbagai usaha bahkan perusahaan harus memiliki strategi agar bertahan di pasar. Salah satu strategi bertahan yang dilakukan oleh perusahaan misalnya perusahaan di bidang plastik dan kemasan adalah dengan menarik minat konsumen melalui plastik dan kemasan suatu produk yang menjadi perhatian utama para konsumen. Strategi ini diharapkan dapat meningkatkan kegiatan usaha di bidang 
plastik dan kemasan sehingga memberikan prospek yang menjanjikan.

Konsumsi plastik dan kemasan di Indonesia diproyeksikan mencapai 1,9 juta ton. Di semester 1 tahun 2013 jumlah tersebut meningkat sekitar 22,58\% dibandingkan dengan tahun sebelumnya sebanyak 1,55 juta ton. Wakil Ketua Umum Asosiasi Olefin Aromatik dan Plastik Indonesia (Inaplas, Budi S Sudirman, mengatakan bahwa nilai penjualan industri plastik dan kemasan di pasar domestik mencapai sekitar Rp47,5 ton dengan asumsi konsumsi 1,9 juta ton. Hal ini memberikan pengaruh yang positif untuk perekonomian Indonesia dan diharapkan konsumsi plastik nasional dapat terus meningkat.

Dalam menilai kinerja laporan keuangan suatu perusahaan, analis atau investor dapat menggunakan rasio-rasio sebagai alat pengukuran keberhasilan kinerja keuangan seperti solvabilitas, likuiditas, dan profitabilitas. Profitabilitas adalah sekelompok rasio yang menunjukan kombinasi dari pengaruh manajemen aset dan utang, (Brigham dan Houston, 2010: 146). Manajemen aset dan utang salah satunya dipengaruhi oleh perputaran total aktiva. Peningkatan terhadap perputaran total aktiva merupakan hasil dari perbaikan dalam perputaran persediaan dan perputaran piutang usaha (Fraser dan Aileen, 2008: 232). Sedangkan menurut Munawir (2007: 89) besarnya Return On Investment (ROI) dipengaruhi oleh dua faktor:

1. Turnover dari operating assets (tingkat perputaran aktiva yang digunakan untuk operasi).

2. Profit margin merupakan besarnya keuntungan operasi perusahaan yang dinyatakan dalam persentase dan jumlah penjualan bersih. Profit margin ini mengukur tingkat keuntungan yang dapat dicapai oleh perusahaan dihubungkan dengan penjualannya.
Selanjutnya, pengembalian atas investasi (ROI) dan pengembalian atas ekuitas (ROE) adalah dua rasio yang umum digunakan untuk mengukur efisiensi keseluruhan perusahaan dalam mengelola total investasinya dalam aktiva dan dalam menghasilkan pengembalian kepada pemegang saham.

\section{TINJAUAN PUSTAKA \\ Teori Rasio Leverage}

Menurut Harjito dan Martono (2012: 53) rasio leverage (financial leverage ratio) adalah rasio yang mengukur seberapa banyak perusahaan menggunakan dana dari hutang (pinjaman). Geoffrey dan Stanley (2013: 100) menyatakan bahwa:

"Leverage represents the use of fixed cost items to magnify the firm's results."

Sedangkan Olivier dan Watney (2000: 13) mengemukakan leverage sebagai berikut:

"The solvency ratio shows the extent to which assets cover liability. It also indicates how easily the enterprise is able to repay loans and debts. It is clearly more difficult for an enterprise to repay its debts if its total liabilities exceed its total assets."

Pengertian Degree of Financial Leverge (DFL) dinyatakan oleh Horne and Warchowicz, (2013: 108) dengan sangat baik yaitu:

"is a quantitative of the sensitivity of a firms earning per share to a change in the firms operating profit."

Selanjutnya Sartono (2010: 265) berpendapat mengenai degree of financial leverage ini sebagai rasio antara persentase perubahan Earning Per Share (EPS) dibanding dengan perubahan Earning Before Interest and Tax (EBIT)."

Penelitian tentang rasio aktivitas, rasio leverage, pertumbuhan penjualan dan ukuran 
perusahaan sudah banyak dilakukan oleh peneliti sebelumnya. Penelitian-penelitian ini diantaranya pada rasio leverage yang diwakili oleh Debt to Equity Ratio (DER) dan DFL yang dilakukan oleh Andreani dan Leliani (2013), yang menyatakan bahwa debt to equity ratio secara parsial tidak berpengaruh terhadap return on investment. Namun hasil penelitian ini berbeda dengan penelitian yang dilakukan oleh Kamaliah dan Nasrizal (2009) yang menyatakan bahwa DER ternyata berpengaruh positif signifikan terhadap ROI.

\section{Teori Pertumbuhan Penjualan}

Pertumbuhan penjualan menunjukkan aktivitas penjualan yang diukur dari penjualan bersih (net sales) sebuah perusahaan. Dengan mengetahui seberapa besar pertumbuhan penjualan, perusahaan dapat memprediksi seberapa besar profit yang akan didapatkan.

Penelitian tentang rasio aktivitas, rasio leverage, pertumbuhan penjualan dan ukuran perusahaan sudah banyak dilakukan oleh peneliti sebelumnya, diantaranya pada pertumbuhan penjualan yang diwakili oleh Sales Growth (SG) yang dilakukan oleh Sunarto dan Agus (2009) yang menyatakan bahwa pertumbuhan penjualan tidak berpengaruh terhadap profitabilitas.

\section{Teori Ukuran Perusahaan}

Menurut Brigham dan Houston (2009:117) ukuran perusahaan dapat didefinisikan sebagai berikut:

"Company size is the average net sales for the year up to several years, in which case the sale is greater than the variable costs and fixed costs, will eat the amount of income earned before taxes. Otherwise if the sale is less than the variable cost and fixed costs, the company will suffer a loss"

Sedangkan Riyanto (2001: 299) mengemukakan bahwa ukuran perusahaan menggambarkan besar kecilnya suatu perusahaan yang ditunjukan pada total aktiva, jumlah penjualan, rata-rata penjualan, dan total aktiva.

Penelitian yang dilakukan oleh peneliti sebelumya, diantaranya pada ukuran perusahaan oleh Azlina (2009), menyatakan bahwa Firm's Size (Size) secara parsial tidak berpengaruh terhadap Return On Investment (ROI). Namun hasil yang berbeda ditemukan dalam penelitian yang dilakukan oleh Kamaliah dan Nasrizal (2009), Andreani dan Leliani (2013), Elfianto (2011), Yusralaini, dkk. (2009), Sunarto dan Agus yang mengemukakan bahwa ukuran perusahaan (Size) berpengaruh positif signifikan terhadap profitabilitas.

\section{Teori Return On Investment (ROI)}

Fraser (1998: 157) menyatakan "return on investment or return on assets indicates the amount of profit earned relative to the level of investment in total asset. Return on invesment ini menunjukkan jumlah keuntungan yang diperoleh terhadap tingkat investasi total aset. Sementara Lawrence (2003: 65) menyatakan bahwa "ROA measures the overall effectiveness of management in generating profits with its available assets, also called the Return On Investment (ROI)." Analisa return on investment dalam analisa keuangan mempunyai arti yang sangat penting yaitu sebagai salah satu tehnik analisa keuangan yang bersifat menyeluruh (komprehensif).

\section{Hipotesis}

Berdasarkan latar belakang dan penelitian terdahulu, penelitian ini bertujuan mengetahui pengaruh rasio leverage, pertumbuhan penjualan dan ukuran perusahaan terhadap ROI pada perusahaan sub sektor plastic dan kemasan yang terdaftar di BEl dari periode tahun 2013 2016. Hipotesis yang dikembangkan terkait dengan topik penelitian adalah sebagai berikut: 
$\mathrm{H}_{1}$ : Terdapat pengaruh positif antara Debt to Equity Ratio (DER) terhadap Return On Investment (ROI) pada perusahaan manufaktur industri dasar dan kimia sub sektor plastik dan kemasan di BEI.

$\mathrm{H}_{2}$ : Terdapat pengaruh positif antara Degree of Financial Leverage (DFL) terhadap Return On Investment (ROI) pada perusahaan manufaktur industri dasar dan kimia sub sektor plastik dan kemasan di BEI.

$\mathrm{H}_{3}$ : Terdapat pengaruh positif antara Sales Growth (SG) terhadap Return On Investment (ROI) pada perusahaan manufaktur industri dasar dan kimia sub sektor plastik dan kemasan di BEl.

$\mathrm{H}_{4}$ : Terdapat pengaruh antara $D E R, D F L, S G$ dan Size secara parsial terhadap Return On Investment (ROI) pada perusahaan manufaktur industri dasar dan kimia sub sektor plastik dan kemasan di BEI.

\section{METODE ANALISIS}

\section{Objek Penelitian}

Objek penelitian pada penelitian ini adalah Debt to Equity Ratio (DER), Degree of Financial Leverage (DFL), Sales Growth (SG), dan Firm's Size (Size) sebagai variabel independen, serta Return On Investment (ROI) sebagai variabel dependen.

\section{Metode Penelitian}

Jenis penelitian yang digunakan dalam penelitian ini adalah penelitian kuantitatif dengan sumber data sekunder. Sedangkan metode penarikan sampel menerapkan purposive sampling. Kemudian, data yang terpilih dikumpulkan melalui metode dokumentasi atau bahan pustaka. Terakhir, untuk melihat pengaruh variabel independen terhadap variabel dependen, metode analisis dalam penelitian ini menggunakan statistik deskriptif dan inferensial yang terdiri dari analisis regresi linier berganda, uji asumsi klasik, dan uji hipotesis.

\section{Hasil Penelitian dan pembahasan}

Berdasarkan Tabel 1, hasil analisis statistik deskriptif (descriptive statistics) dapat dilihat bahwa ROI mempunyai $\mathrm{N}$ (jumlah data) sebanyak 30 . Nilai minimum yaitu $-0,12$, nilai maximum 0,17 . Nilai mean sebesar 0,0197, sedangkan standar deviation (ukuran penyebaran data dari rata-rata) sebesar 0,05780 .

Tabel 1

Descriptive Statistics

\begin{tabular}{|l|r|r|r|r|r|}
\hline & $\mathrm{N}$ & Minimum & Maximum & Mean & $\begin{array}{c}\text { Std. } \\
\text { Deviation }\end{array}$ \\
\hline DFL & 30 & -4.02 & 6.91 & 1.1670 & 1.99327 \\
DER & 30 & -4.12 & 2.68 & .9413 & 1.19286 \\
SG & 30 & .00 & 5.91 & .3210 & 1.06091 \\
SIZE & 30 & 24.61 & 29.24 & 27.3930 & 1.36202 \\
ROI & 30 & -.12 & .17 & .0197 & .05780 \\
Valid N & 30 & & & & \\
(listwise) & & & & & \\
\hline
\end{tabular}

Nilai DFL dari Tabel 1 menunjukkan nilai rata-rata (mean) sebesar 1,1670 atau $116,70 \%$. DFL minimum sebesar $-4,02$ atau $402 \%$ dan DFL maximum sebesar 6,91 atau 691\%. Std. Deviation menunjukkan penyebaran data dari rata-rata nilai sebesar
199,327\%. Tabel 1 juga menunjukkan nilai dari Debt to Equity Ratio (DER). Nilai rata-rata (mean) DER sebesar 0,9413 atau 9,413\%. DER minimum sebesar -4.12 atau $-412 \%$ dan DER maximum sebesar 2,68 atau 268\%. Std. Deviation DER memiliki penyebaran data dari 
rata-rata nilai sebesar 1,19286 atau $119,286 \%$.

Selanjutnya, Sales Growth (SG) di Tabel 1 memiliki nilai rata-rata (mean) sebesar 0,3210 atau 3,210\%. Nilai minimum sebesar 0,00 atau $0 \%$ dan nilai maximum sebesar 5,91 atau 591\%. Dengan nilai Std. deviation sebesar 1,06091 atau 106,091\%. Dan terakhir, untuk Firm's Size (Size), Tabel 1 memperlihatkan bahwa nilai rata-rata Size sebesar 27,3930 atau 2.739,30\%. Nilai minimum sebesar 24,61 atau $2,461 \%$ dan nilai maximum sebesar 29,24 atau 2,924\%. Serta Std. deviation penyebaran data dari rata-rata nilai sebesar 1,36202 atau $126,202 \%$.

Untuk menganalisis pengaruh antara variabel dependen dan independen dalam penelitian ini, analisis regresi berganda digunakan. Analisis regresi berganda adalah analisis untuk mengukur besarnya pengaruh antara dua atau lebih variabel independen terhadap satu variabel dependen dan memprediksi variable dependen dengan menggunakan variabel independen (Priyatno, 2012: 127).

Hasil dari implementasi regresi linier berganda dapat dilihat di Tabel 2 berikut (hasil output coefficients).

Tabel 2.

Regresi Linier Berganda

Coefficients $^{\mathrm{a}}$

\begin{tabular}{|l|r|r|r|r|r|}
\hline Model & \multicolumn{2}{|c|}{$\begin{array}{l}\text { Unstandardize } \\
\mathrm{d} \text { Coefficients }\end{array}$} & $\begin{array}{c}\text { Standard } \\
\text { ized } \\
\text { Coefficie } \\
\text { nts }\end{array}$ & \multicolumn{1}{c|}{$\mathrm{t}$} & Sig. \\
\cline { 2 - 4 } & B & \multicolumn{1}{c|}{$\begin{array}{c}\text { Std. } \\
\text { Error }\end{array}$} & \multicolumn{1}{c|}{ Beta } & & \\
\hline (Constant) & .291 & .217 & & 1.339 & .194 \\
DFL & .003 & .004 & .116 & .761 & .455 \\
DER & .014 & .009 & .286 & 1.606 & .122 \\
SG & .005 & .009 & .093 & .583 & .566 \\
SIZE & -.013 & .008 & -.300 & -1.575 & .129 \\
\hline
\end{tabular}

a. Dependent Variable: ROI

Berdasarkan Tabel 2 di atas, hasil analisis regresi linier berganda dapat dimasukkan ke dalam rumus sebagai berikut:

$$
\mathrm{ROI}=0,291+0,003 \mathrm{DFL}+0,014 \mathrm{DER}+0,005
$$

Berikut ini merupakan penjelasan dari persamaan regresi linier berganda tersebut:

1) Nilai konstanta adalah 0,291 , artinya jika, $D F L, D E R, S G$ dan Size nilainya adalah 0 maka Return On Investment nilainya yaitu 0,291.
2) Nilai koefisien regresi variabel $\operatorname{DER}\left(X_{1}\right)$ bernilai positif, yaitu 0,014 . Artinya setiap peningkatan $D E R$ sebesar satu satuan maka $R O I$ akan-naik 0,014 dengan asumsi variabel independen lain nilainya tetap. 
3) Nilai koefisien regresi variabel DFL $\left(X_{2}\right)$ bernilai positif, yaitu 0,003 . Artinya setiap peningkatan DFL sebesar satu satuan maka $R O I$ akan naik 0,003 dengan asumsi variabel independen lain nilainya tetap.

4) Nilai koefisien SG $\left(X_{3}\right)$ bernilai positif, yaitu 0,005. Artinya bahwa setiap peningkatan $S G$ sebesar satu satuan maka $R O I$ akan naik sebesar 0,005 dengan asumsi variabel independen lain nilainya tetap.
5) Nilai koefisien Size $\left(X_{4}\right)$ bernilai negative, yaitu -0,013. Artinya bahwa setiap peningkatan Size sebesar satu satuan maka $R O I$ akan menurun $-0,013$ dengan asumsi variabel independen lain nilainya tetap.

Tabel 3 merupakan hasil dari perhitungan nilai korelasi berganda (R), koefisien determinasi yang disesuaikan (adjusted $R$ square), dan dan ukuran kesalahan prediksi (std. error of the estimate)

Tabel 3.

Nilai Korelasi Berganda Model Summary ${ }^{b}$

\begin{tabular}{|l|c|r|r|c|}
\hline $\begin{array}{l}\text { Mode } \\
\mathrm{l}\end{array}$ & $\mathrm{R}$ & $\begin{array}{c}\mathrm{R} \\
\text { Squar } \\
\mathrm{e}\end{array}$ & $\begin{array}{c}\text { Adjusted } \\
\text { R Square }\end{array}$ & $\begin{array}{c}\text { Std. } \\
\text { Error of } \\
\text { the } \\
\text { Estimate }\end{array}$ \\
\hline 1 & $\begin{array}{r}.724 \\
\mathrm{a}\end{array}$ & .524 & .400 & .04479 \\
\hline
\end{tabular}

a. Predictors: (Constant), SIZE, DFL, SG, DER

b. Dependent Variable: ROI

Berikut ini merupakan penjelasan dari Tabel

3 , output model summary.

a) $\mathrm{R}$ menunjukkan nilai korelasi berganda, yaitu korelasi antara dua atau lebih variabel independen terhadap variabel dependen. Nilai $\mathrm{R}$ berkisar antara 0 sampai 1, jika mendekati 1 maka hubungan semakin erat, tetapi jika mendekati 0 maka hubungan semakin lemah. Angka $R$ yang didapat 0,724, artinya korelasi antara $D E R, D F L, S G$ dan Size terhadap $R O I$ sebesar 0,724 atau $72,4 \%$.

b) $\mathrm{R}$ square atau kuadrat dari $\mathrm{R}$, yaitu menunjukkan koefisien determinasi. Persentase sumbangan pengaruh variabel independen terhadap variabel dependen. Nilai $R^{2}$ berkisar 0,524 artinya pesentase sumbangan pengaruh $D F L$, $D E R, S G$ dan Size terhadap $R O I$ sebesar 0,531 atau $53,1 \%$, sisanya dipengaruhi oleh variabel lain yang tidak dimasukkan dalam model ini.

c) Adjusted R square, adalah $\mathrm{R}$ square yang telah disesuaikan, nilai sebesar 0,400 atau $40 \%$ ini juga menunjukkan sumbangan pengaruh, DFL, DER, SG dan size terhadap return on investment.

d) Standard error of the estimate, adalah ukuran kesalahan prediksi, nilai sebesar 0,04479. artinya kesalahan yang dapat terjadi dalam memprediksi ROI sebesar 0,04479 atau $4,479 \%$.

Untuk memperoleh model regresi dengan estimasi yang tidak bias dan pengujian dapat dipercaya, maka uji asumsi klasik haruslah terpenuhi.

1) Uji Normalitas

Tabel 4 menunjukan hasil dari uji normalitas menggunakan one-sample Kolmogorov-Smirnov Test. 
Tabel 4.

One-Sample Kolmogorov-Smirnov Test

\begin{tabular}{|ll|r|}
\hline & & $\begin{array}{c}\text { Unstandardized } \\
\text { Residual }\end{array}$ \\
\hline $\mathrm{N}$ & 30 \\
Normal & Mean & $0 \mathrm{E}-7$ \\
Paramet & Std. & .03988851 \\
ers & Deviation & .078 \\
Most & Absolute & .078 \\
Extreme & Positive & -.074 \\
Differenc & Negative \\
es & Kolmogorov-Smirnov & .427 \\
Z & & .993 \\
Asymp. Sig. (2-tailed)
\end{tabular}

a. Test distribution is Normal.

b. Calculated from data.

Berdasarkan output di Tabel 4 di atas, dapat diketahui bahwa nilai Asymp. Sig. (2tailed) sebesar 0,993. Karena signifikan lebih dari 0,05 (0,993>0,05), maka dengan demikian dapat disimpulkan bahwa nilai residual tersebut adalah normal.
2) Uji Multikolinearitas

Tabel 5 menunjukan hasil dari uji multikolinearitas menggunakan tolerance dan VIF.

Tabel 5.

Uji Multikolinearitas

Coefficients $^{\text {a }}$

\begin{tabular}{|c|c|c|c|c|c|c|c|}
\hline \multirow[t]{2}{*}{ Model } & \multicolumn{2}{|c|}{$\begin{array}{c}\text { Unstandardized } \\
\text { Coefficients }\end{array}$} & \multirow{2}{*}{$\begin{array}{l}\text { Stand } \\
\text { ardize } \\
d \\
\text { Coeffi } \\
\text { cients } \\
\text { Beta }\end{array}$} & \multirow[t]{2}{*}{$\mathrm{T}$} & \multirow[t]{2}{*}{ Sig. } & \multicolumn{2}{|c|}{$\begin{array}{c}\text { Collinearity } \\
\text { Statistics }\end{array}$} \\
\hline & B & $\begin{array}{l}\text { Std. } \\
\text { Error }\end{array}$ & & & & $\begin{array}{c}\text { Toleran } \\
\text { ce }\end{array}$ & VIF \\
\hline (Constant) & .291 & .217 & & 1.339 & 194 & & \\
\hline DFL & .003 & .004 & . 116 & .761 & .455 & .886 & 1.129 \\
\hline DER & .014 & .009 & .286 & 1.606 & .122 & .653 & 1.530 \\
\hline SG & .005 & .009 & .093 & .583 & .566 & .806 & 1.240 \\
\hline SIZE & -.013 & .008 & -.300 & -1.575 & .129 & .570 & 1.755 \\
\hline
\end{tabular}

a. Dependent Variable: ROI

Dari output di atas, dapat diketahui bahwa nilai tolerance dan nilai VIF keenam variabel independen lebih dari 0,10 dan kurang dari 10. Maka dapat dikatakan tidak terjadi masalah multikolinearitas pada model regresi.

3) Uji Heterokedastisitas 
Tabel 6 menunjukan hasil dari uji Heteroskedastisitas.

Tabel 6.

Uji Heteroskedastisitas

Coefficients $^{\mathrm{a}}$

\begin{tabular}{|l|r|r|r|r|r|r|r|}
\hline Model & \multicolumn{2}{|c|}{$\begin{array}{c}\text { Unstandardiz } \\
\text { ed } \\
\text { Coefficients }\end{array}$} & $\begin{array}{c}\text { Standar } \\
\text { dized } \\
\text { Coeffici } \\
\text { ents }\end{array}$ & $\mathrm{T}$ & \multicolumn{2}{|c|}{ Sig. } & \multicolumn{2}{|c|}{$\begin{array}{c}\text { Collinearity } \\
\text { Statistics }\end{array}$} \\
\cline { 2 - 8 } & B & $\begin{array}{c}\text { Std. } \\
\text { Error }\end{array}$ & Beta & & & $\begin{array}{r}\text { Tole } \\
\text { ranc } \\
\mathrm{e}\end{array}$ & VIF \\
\hline (Constant) & .104 & .116 & & .900 & .378 & & \\
DFL & -.001 & .002 & -.106 & -.571 & .574 & .886 & 1.129 \\
DER & -.005 & .005 & .004 & .020 & .984 & .653 & 1.530 \\
SG & -.005 & .005 & -.231 & -1.180 & .250 & .806 & 1.240 \\
SIZE & -.003 & .004 & -.145 & -.623 & .540 & .570 & 1.755 \\
\hline
\end{tabular}

a. Dependent Variable: ABS_RES

Berdasarkan output tabel 6 di atas,

4) Uji Autokorelasi

dapat diketahui bahwa nilai signifikan Tabel 7 menunjukan hasil dari uji autokorelasi keenam variabel di atas lebih dari 0,05. dengan menggunakan Durbin-Watson.

Dengan demikian dapat disimpulkan bahwa

tidak terjadi masalah heteroskedastisitas

pada model regresi.

Tabel 7.

Uji Autokorelasi

Model Summary ${ }^{b}$

\begin{tabular}{|l|r|r|r|r|r|}
\hline Model & $\mathrm{R}$ & $\begin{array}{c}\mathrm{R} \\
\text { Square }\end{array}$ & $\begin{array}{r}\text { Adjusted } \\
\text { R Square }\end{array}$ & $\begin{array}{c}\text { Std. Error of } \\
\text { the Estimate }\end{array}$ & $\begin{array}{r}\text { Durbin- } \\
\text { Watson }\end{array}$ \\
\hline 1 & $\begin{array}{r}.724 \\
\mathrm{a}\end{array}$ & .524 & .400 & .04479 & 1.432 \\
\hline
\end{tabular}

a. Predictors: (Constant), SIZE, DFL, SG, DER

b. ROI

JIMFE (Jurnal Ilmiah Manajemen Fakultas Ekonomi)

Volume 3 No. 2 Tahun 2017, Hal. 60-69 
Hasil uji autokorelasi ini memperlihatkan bahwa angka D-W sebesar 1,432 . Karena nilai 1,432 berada di antara -2 s.d. +2 , hal ini menunjukan bahwa model regresi dalam penelitian ini tidak terdapat masalah autokorelasi.

Pengaruh Debt to Equity Ratio (DER) terhadap Return On Investment (ROI)

Hasil pengujian statistik dengan melakukan uji regresi menyatakan bahwa Debt to Equity Ratio (DER) secara parsial tidak berpengaruh signifikan terhadap $R O I$. nilai $\mathrm{t}$ hitung untuk Debt to Equity Ratio (DER) adalah 1,606. Karena nilai $-\mathrm{t}$ tabel $<\mathrm{t}$ hitung $<$ t tabel $(-2,068<1,606<2,068)$ maka Ho diterima, Dengan demikian hipotesis satu $\left(\mathrm{H}_{1}\right)$ ditolak.

\section{Pengaruh Degree of Financial Leverage (DFL) terhadap Return On Investment (ROI)}

Hasil pengujian statistik dengan melakukan uji regresi menyatakan bahwa Degree of Financial Leverage (DFL) secara parsial tidak berpengaruh signifikan terhadap ROI. Nilai t hitung untuk Degree of Financial Leverage (DFL) adalah 0,761. Karena nilai $-\mathrm{t}$ tabel $<$ t hitung $<$ t tabel $(-2,068<0,761<$ $2,068)$ maka Ho diterima. Dengan demikian hipotesis dua $\left(\mathrm{H}_{2}\right)$ ditolak.

Pengaruh Pertumbuhan Penjualan (Sales Growth) terhadap Return On Investment (ROI)

Hasil pengujian statistik dengan melakukan uji regresi menyatakan bahwa Sales Growth (SG) secara parsial tidak berpengaruh signifikan terhadap Return On Investment. Nilai t hitung untuk Sales Growth (SG) adalah 0,583. Karena nilai $-\mathrm{t}$ tabel $<\mathrm{t}$ hitung $<\mathrm{t}$ tabel $(-2,068<0,583<2,068)$ maka Ho diterima. Dengan demikian hipotesis tiga $\left(\mathrm{H}_{3}\right)$ ditolak.

Pengaruh Ukuran Perusahaan (Size) terhadap Return On Investment (ROI)
Hasil pengujian statistik dengan melakukan uji regresi menyatakan bahwa Firm's Size (Size) secara parsial tidak berpengaruh signifikan terhadap Return On Investment. Nilai $\mathrm{t}$ hitung untuk Firm's Size (Size) adalah $-1,575$. Karena nilai $-\mathrm{t}$ tabel $<\mathrm{t}$ hitung $<\mathrm{t}$ tabel $(-2,068<-1,575<2,068)$ maka Ho diterima. Dengan demikian hipotesis empat $\left(\mathrm{H}_{4}\right)$ ditolak.

Pengaruh Rasio Leverage, Pertumbuhan Penjualan dan Ukuran Perusahaan terhadap Return On Investment (ROI)

Hasil pengujian statistik dengan melakukan uji regresi menyatakan bahwa $D E R, D F L, S G$ dan Size berpengaruh positif dan signifikan terhadap ROI. Hasil yang diperoleh untuk $\mathrm{F}$ table sebesar 2,53. Karena $\mathrm{F}$ hitung $>\mathrm{F}$ table $(4,217>2,53)$ maka Ho ditolak. Dengan demikian hipotesis empat $\left(\mathrm{H}_{4}\right)$ diterima.

\section{PENUTUP}

Berdasarkan hasil penelitian dan pembahasan sebelumnya, maka dapat disimpulkan bahwa dari 2 variabel independen terdapat 2 variabel yang berpengaruh signifikan terhadap Return On Investment (ROI) Sedangkan secara parsial, variabel $D E R, D F L, S G$ dan Size berpengaruh signifikan terhadap Return On Investment (ROI).

\section{DAFTAR PUSTAKA}

Barus, A.C dan Leliani (2013), Analisis FaktorFaktor yang Mempengaruhi Pprofitabilitas pada Perusahaan Manufaktur yang Terdaftar di BEl. Jurnal Wira Ekonomi Mikroskil. Vol.3, No.2

Brigham, Eugene $F$ and Joel F. Houston. (2010), Dasar-Dasar Manajemen Keuangan, Salemba Empat : Jakarta

Priyatno, Duwi (2012), Cara Kilat Belajar Analisis Data dengan SPSS 20, Penerbit ANDI. Yogyakarta 
Brigham, Eugene F., Michael C. Ehrhardt (2013), Financial Management theory and Practic, Ninth Edition, Florida.

Gitman, Lawrence J. (2003), Principles of Managerial Finance, Tenth Edition, Pearson Education, Inc., United States.

Satriya, I Made Dian, dan Putu Vivi Lestari (2012), Pengaruh Perputaran Modal Kerja Terhadap Profitabilitas Perusahaan Real Estate dan-Property, Skripsi, Universitas Udayana, Bali.

Kamaliah, Nasrizal Akbar dan Lexinta Kinanti (2009), Analisis Pengaruh Rasio Aktivitas, Laverage Keuangan, Ukuran dan Umur Perusahaan Terhadap Profitabilitas Perusahaan Whole sale and Retail Trade yang Terdaftar di BEI. Jurnal Ekonomi. Vol.17 No.3.

Fraser, Lyn M. \& Aileen Ormiston (2008), Memahami Laporan Keuangan, Edisi ke tujuh, Penerbit Indeks.

Martono, SU, dan D. Agus Harjito (2010), Manajemen Keuangan, Cetakan Kedelapan, Penerbit Ekonisia, Yogyakarta.

Munawir (2007), Analisa Laporan Keuangan. Cetakan Keempat belas. Penerbit Liberty, Yogyakarta.

Nugroho, elfianto (2011), Analisis Pengaruh Likuid, Pertumbuhan Penjualan, Perputaran Modal Kerja, Ukuran Perusahaan dan Leverage terhadap Profitabilitas Perusahaan. Skripsi, Universitas Diponegoro. Semarang
Azlina, Nur (2009) Pengaruh Tingkat Perputaran Modal Kerja, Struktur Modal, dan Skala Perusahaan Terhadap Profitabilitas. Pekbis Jurnal. Vol.1 No.2

Posthumus, LC, N Basson, P Olivier, and A Watney (2000), Principles of Financial Management. Kenwyn, Juta and Co.Ltd.

Riyanto, Bambang (2001), Dasar-dasar Pembelajaran Perusahaan. BPFE : Yogyakarta.

Rosdiana, Resta dan Asmirantho, Edhi (2014), Influence Against Receivable Management Capabilities In Producing Income-

On the Basic Industry and Chemical Company Sub Sector FEED Listed in Indonesia Stock Exchange. Skripsi. Universitas Pakuan. Bogor.

Sartono, Agus (2010), Manajemen Keuangan Teori dan Aplikasi. Edisi ke Empat, BPFE : Yogyakarta.

Sunarto, dan Budi, A.P (2009), Pengaruh Leverage, Ukuran dan Pertumbuhan Perusahaan Terhadap Profitabilitas. Telaah Manajemen Marlien (TEMA) Vol.6 Edisi.1 hal. 81-103

Yusralaini, Amir Hasan dan Imelga Helen (2009), Pengaruh perputaran Modal Kerja, Struktur Modal, Umur Perusahaan, dan Ukuran Perusahaan terhadap Profitabilitas. Jurnal Ekonomi. Vol. 17, No.3 ISSN 0853-7593

www.sahamok.com

www.idx.co.id www.kemenperin.go.id 